\title{
MDM2 regulates estrogen receptor $\alpha$ and estrogen responsiveness in breast cancer cells
}

\author{
Kyounghyun Kim ${ }^{1,2}$, Robert Burghardt ${ }^{3}$, Rola Barhoumi ${ }^{3}$, Syng-ook Lee ${ }^{2}$, Xinyi Liu ${ }^{4}$ \\ and Stephen Safe ${ }^{1,2}$
}

${ }^{1}$ Department of Veterinary Physiology and Pharmacology, Texas A\&M University, 4466 TAMU, Veterinary Research Building 410, College Station, Texas 77843-4466, USA
${ }^{2}$ Institute of Biosciences and Technology, Texas A\&M University Health Science Center, Houston, Texas 77030, USA

Departments of ${ }^{3}$ Veterinary Integrative Biosciences and ${ }^{4}$ Biochemistry and Biophysics, Texas A\&M University, College Station, Texas 77843 , USA

(Correspondence should be addressed to S Safe at Department of Veterinary Physiology and Pharmacology, Texas A\&M University; Email: ssafe@cvm.tamu.edu)

\begin{abstract}
Murine double minute clone 2 (MDM2) is a multifunctional protein, which modulates nuclear receptor-mediated transactivation. In this study, we show that MDM2 significantly enhanced estrogen receptor $\alpha(E R \alpha)$ and ER $\alpha /$ specificity protein-mediated transactivation in MCF-7 and ZR-75 breast cancer cells. This was demonstrated by both MDM2 overexpression and knockdown experiments by RNA interference. ER $\alpha$ interacted with wild-type MDM2 and deletion mutants of MDM2 containing amino acids 1-342 (C-terminal deletion) and 134-490 ( $\mathrm{N}$-terminal deletion), but not 134-342. In contrast, only wild-type but not mutant MDM2 enhanced ER $\alpha$-mediated transactivation. Protein-protein interactions in vitro were $17 \beta$-estradiol $\left(E_{2}\right)$ independent, whereas fluorescent resonance energy transfer experiments in living cells showed that $E_{2}$ enhanced $E R \alpha-M D M 2$ interactions. Subsequent RNA interference and mammalian twohybrid experiments suggested that MDM2 did not directly interact with endogenous coactivators such as the steroid receptor coactivators but played a role in enhancing $\mathrm{ER} \alpha$-mediating gene expression and estrogen responsiveness through interactions with $\mathrm{ER} \alpha$.
\end{abstract}

Journal of Molecular Endocrinology (2011) 46, 67-79

\section{Introduction}

Murine double minute clone 2 (MDM2) was initially cloned from a transformed 3T3 cell line, and later identified as a p53-interacting protein (Cahilly-Snyder et al. 1987, Fakharzadeh et al. 1991, Momand et al. 1992). It was subsequently shown that overexpression of MDM2 resulted in cell transformation and oncogenicity and this was due, in part, to suppression of the tumor suppressor gene $p 53$. The complex interrelationships between MDM2 and p53 have been extensively investigated (Levav-Cohen et al. 2005, Brooks \& Gu 2006). MDM2 exhibits E3-ubiquitin ligase activity, which increases ubiquitination of p53 and, in combination with other factors, the resulting proteasome-dependent degradation of p53 decreases expression of this tumor suppressor gene under nonstressed conditions (Ashcroft et al. 1999, Kubbutat $e t$ al. 1999). The role of MDM2 in regulating p53 expression is also apparent in transgenic mice where MDM2 knockout animals exhibit embryolethality, which is reversed by inactivation of $\mathrm{p} 53$ (Jones et al. 1995, Montes de Oca Luna et al. 1995, de Rozieres et al. 2000). Under conditions of cellular stress, the physical and functional interactions of MDM2 and p53 are inhibited, thereby allowing p53 to activate gene expression pathways, such as inhibition of cell cycle progress and induction of apoptosis, which allow the cells to respond to stressors. The interactions between p53 and MDM2 are complex and are modified under various conditions and in a cell/tissue context-dependent manner (Brooks \& Gu 2006).

Since MDM2 inhibits p53 function as a tumor suppressor gene, it is not surprising that expression of MDM2 plays a role in cancer and in cancer prognosis (Levav-Cohen et al. 2005). Overexpression of MDM2 is frequently observed in many different cancers; however, the prognosis for patients in which MDM2 levels are high is dependent on multiple factors including the type of tumor and its origin. For example, MDM2 overexpression through gene amplification in gliomas predicts poor survival (Korkolopoulou et al. 1997, Rainov et al. 1997, Schiebe et al. 2000), whereas overexpression through gene amplification in breast cancer is observed only in estrogen receptor (ER)positive tumors for which there is a good prognosis for survival (Bueso-Ramos et al. 1996, Lukas et al. 2001, Hori et al. 2002). The variability of MDM2 as a prognostic indicator for cancer survival is complex and may be due to interactions with other unknown factors.

A number of p53-independent functions of MDM2 have been identified and show that this protein can modify different signaling pathways. MDM2 interacts 
with and inhibits the function of retinoblastoma $(\mathrm{Rb})$ protein and other Rb family members (Hsieh et al. 1999) and this affects E2F1-DP1-mediated responses (Martin et al. 1995) and also enhances the transcriptional activation of cyclin A (Leveillard \& Wasylyk 1997). MDM2 also modulates ligand-dependent activation of several steroid hormone receptors including the glucocorticoid receptor, androgen receptor, and ER (Liu et al. 2000, Saji et al. 2001, Sengupta \& Wasylyk 2004). MDM2 overexpression in MCF-7 human breast cancer cells enhances their estrogen-dependent growth and, in p53deficient Saos-2 osteosarcoma cells and MCF-7 cells, MDM2 enhances 17ß-estradiol ( $\left.\mathrm{E}_{2}\right)$-dependent activation of a construct containing an estrogen response element (ERE) insert (Saji et al. 2001).

This study shows by RNA interference that MDM2 enhances $\mathrm{E}_{2}$-dependent growth and transactivation in breast cancer cells using constructs containing three tandem EREs or GC-rich motifs ( $\mathrm{pSP} 1_{3}$ ) activated by ER $\alpha$ or $\mathrm{ER} \alpha / \mathrm{SP} 1$ respectively. MDM2 overexpression also coactivates ER $\alpha$ and $\mathrm{ER} \alpha / \mathrm{SP} 1$, and the results suggest that the coactivation response is primarily through direct interactions of MDM2 with ER $\alpha$ and MDM2-dependent enhanced interactions of $\mathrm{ER} \alpha$ with coactivators.

\section{Materials and methods}

\section{Cell lines, chemicals, and biochemicals}

The ZR-75 (ZR-75.1), MCF-7, and T47D human breast cancer cell lines were obtained from the American Type Culture Collection (ATCC, Manassas, VA, USA). Cells were cultured in RPMI 1640 or DMEM (Sigma) supplemented with 5 or $10 \%$ FBS and the medium was further supplemented with antibiotic/antimycotic solution (Sigma). Prior to transfection, RPMI or DMEM medium was replaced by DMEM/F-12 (Sigma) supplemented with charcoal-stripped $10 \%$ FBS. Cells were maintained at $37^{\circ} \mathrm{C}$ with a humidified $\mathrm{CO}_{2} /$ air (5:95) mixture. Small inhibitory RNA (siRNA) duplexes for MDM2 (siMDM2), p53 (sip53), luciferase (siGL2), and the scrambled siRNA (siCT) were purchased either from Ambion (Austin, TX, USA) or Sigma-Aldrich. The sequence for siGL2: 5'-CGU ACG CGG AAU ACU UCG ATT-3'; for siMDM2: 5'-GAA CAA GAG ACC CTG GTT A-3' ; for sip53: 5'-GAG GUU GGC UCU GAC UGU A-3'; for scrambled RNA (siCT): 5'-ACU CUA UCU GCA CGC UGA CTT-3'.

\section{Plasmids and cloning}

$\mathrm{pERE}_{3}, \mathrm{pSP}_{3}, \mathrm{pCAD}$, and $\mathrm{pE} 2 \mathrm{~F} 1$ were previously generated in our laboratory. pcDNA-MDM2 (490 aa) was kindly provided by Dr Lane (University of Dundee, UK). The MDM2 deletion mutants (135-490 aa, 135-342 aa, and 1-342 aa) were generated by cloning MDM2 deletion mutant amplified PCR products into EcoRI/ XhoI sites of pcDNA3.1His plasmid. MDM2 deletion mutants were generated by PCR using following primer sets: 1-342 aa: (F) 5'-GAA TTC ATG TGC AAT ACC AAC ATG TC-3', (R) $5^{\prime}$-CTC GAG TTT TTC AGA GAT TTC CAC-3'; 134-490 aa: (F) 5'-GAA TTC CCT TTG CAA GCG CCA CCA G-3' , (R) 5'-CTC GAG CTA GTT GAA GTAAGT TAG CAC-3'; 135-342 aa: (F) 5' $5^{\prime}$-GAA TTC CCT TTG CAA GCG CCA CCA G-3 ${ }^{\prime}$, (R) $5^{\prime}$-CTC GAG TTT TTC AGA GAT TTC CAC-3'. These generated Xpress-tagged expression plasmids were also used for in vitro coimmunoprecipitation assays. pMMDM2 and VP-MDM2 expression plasmids were generated by PCR amplification of MDM2 wild-type and cloned into EcoRI and HindIII sites of pM and VP16 vectors (Clontech). For ECFPMDM2 vector generation, the amplified MDM2 PCR product was digested with EcoRI and XhoI, and cloned into CFP-C1 vector (Clontech). The GAL4-coactivator fusion plasmids pMSRC-1, pMGRIPwt, and pMAIB-1 were kindly provided by Dr Shigeaki Kato (University of Tokyo, Tokyo, Japan), and pMGRIP(LXXLL) (fused to the yeast GAL4 DBD) was obtained from Dr Donald McDonnell (Duke University, Durham, NC, USA).

\section{Transient transfection assays}

The cells were seeded into 12-well plates in phenol-free DMEM/F-12 supplemented with 5\% charcoal-stripped FBS. After $24 \mathrm{~h}$, cells were transfected by lipofectamine 2000 reagent (Invitrogen) with $250 \mathrm{ng}$ of an appropriate reporter plasmid ( $\mathrm{pERE}_{3}, \mathrm{pSP}_{3}$, $\mathrm{pCAD}, \mathrm{pE} 2 \mathrm{~F} 1$, or GAL4luciferase), $50 \mathrm{ng}$ of a CMV $\beta$-galactosidase expression plasmid, and other appropriate expression plasmids (125 ng/well) (ER $\alpha$, MDM2 wild-type and mutants (1-342 aa, 134-490 aa, and 134-490 аa)), pMER $\alpha$, pMMDM2, VP-ER $\alpha$, or VP-MDM2. Empty vectors or nonspecific (siCT) oligonucleotides were used as controls in all transfection experiments. After transfection for $24 \mathrm{~h}$, cells were treated with $\mathrm{Me}_{2} \mathrm{SO}$ or $10 \mathrm{nmol} / 1 \mathrm{E}_{2}$ with $5 \%$ stripped serum media for $24 \mathrm{~h}$. In cells transfected with siRNA(s), $\mathrm{E}_{2}$ was added after $36-48 \mathrm{~h}$ for accomplishing efficient knockdown of target gene. Cells were then harvested, and luciferase activity (relative to $\beta$-galactosidase activity) was determined. Normalized luciferase values were obtained by dividing the luciferase by the $\beta$-galactosidase activities for a given sample. The results are expressed as means \pm s.E.M. for at least three separate experiments for each treatment group.

\section{In vitro coimmunoprecipitation assay}

$\left[{ }^{35} \mathrm{~S}\right] \mathrm{ER} \alpha, \quad\left[{ }^{35} \mathrm{~S}\right] \mathrm{MDM} 2 \mathrm{wt}, \quad\left[{ }^{35} \mathrm{~S}\right] \mathrm{MDM} 2(1-342$ aa $)$, $\left[{ }^{35} \mathrm{~S}\right] \mathrm{MDM} 2$ (134-342 aa), or $\left[{ }^{35} \mathrm{~S}\right] \mathrm{MDM} 2$ (134-490 aa) were in vitro translated using the T7 QuikCoupled 
Transcription Translation System (Promega Corp.). MDM2 wild-type and all mutants were Xpress tagged. $\left[{ }^{35} \mathrm{~S}\right] \mathrm{ER} \alpha(1 \mu \mathrm{l})$ and ${ }^{35}$ S-labeled MDM2 wild-type or deletion mutant protein $(0.5 \mu \mathrm{l})$ were coincubated in coimmunoprecipitation buffer (sterilized PBS + 0.01\% IGEPAL CA630) with $\mathrm{E}_{2}$ to give a final concentration of $100 \mathrm{nM} \mathrm{E}_{2}$. After incubation for $1 \mathrm{~h}$ at $4{ }^{\circ} \mathrm{C}, 25 \mu \mathrm{l}$ of $50 \%$ slurry of protein G-sepharose beads (Amersham Biosciences) were added to the incubation solution, followed by incubation for $2 \mathrm{~h}$ on a rocker at $4{ }^{\circ} \mathrm{C}$. Samples were then centrifuged and washed, the final pellet was boiled in $30 \mu \mathrm{l}$ of $2 \times$ SDS sample buffer, and proteins were separated on a $8 \%$ SDS-PAGE and visualized by autoradiography.

\section{Western blot analysis}

Depletion of MDM2 protein was determined, $48 \mathrm{~h}$ after transfection with siRNA for MDM2, breast cancer cells were harvested with RIPA lysis buffer $(1 \times$ PBS, $1 \%$ Nonidet P-40 or Igepal CA-630, $0.5 \%$ sodium deoxycholate, $0 \cdot 1 \%$ SDS, $1 \mathrm{mg} / \mathrm{ml}$ phenylmethylsulfonyl fluoride in isopropanol, aprotinin, and $100 \mathrm{nM}$ sodium orthovanadate), and equal amounts of protein from each group were boiled with sample buffer and loaded onto 8\% SDS-polyacrylamide gel. The membrane was blocked and probed with primary antibodies for MDM2 (Santa Cruz Biotechnology, Santa Cruz, CA, USA) O/N at $4{ }^{\circ} \mathrm{C}$. Membrane was visualized using the ECL detection system (PerkinElmer Life Sciences, Boston, MA, USA).

\section{Cell proliferation assay}

MCF-7 or ZR-75 cells $\left(5 \times 10^{4}\right.$ per well) were plated into 12-well plates and allowed to attach for $24 \mathrm{~h}$, and then cells were transfected with either control siRNA or MDM2 siRNA. After $24 \mathrm{~h}$, the medium was changed to charcoal-stripped 5\% FBS DMEM medium containing either vehicle (DMSO) or estrogen $(10 \mathrm{nM})$. Fresh medium was added every $48 \mathrm{~h}$. Cells were then trypsinized and counted at the indicated times using a Coulter Z1 particle counter. Each experiment was performed in triplicate and the results are expressed as means \pm s.E.M. for each treatment group.

\section{Quantitative RT-PCR}

RNA was harvested from T47D cells using the RNeasy mini or micro kits (Qiagen). First-strand cDNA synthesis was performed with $1 \mu \mathrm{g}$ RNA using Reverse Transcription kit from Promega. Real-time PCR was performed using SYBR Green PCR Master Mix reagent, the ABI PRISM 7000 sequence detection system, and software (Applied Biosystems, Foster City, CA, USA).
The primer sets were for CAD: (F) 5'-ACC ACG ACA CCT GAA AGA CC-3 ${ }^{\prime}$, (R) $5^{\prime}$-TAC TGG TGG TGG AGG GTA GC-3'; for pS2: (F) 5'-CAC CAT GGA GAA CAG GTG A-3 ${ }^{\prime}$, (R) $5^{\prime}$-AGC CCT TAT TTG CAC ACT GG-3'; for cyclin D1: (F) 5'-CGA TGC CAA CCT CCT CAA CGA-3' ${ }^{\prime}$, (R) $5^{\prime}$-TCG CAG ACC TCC AGC ATC CA-3' ${ }^{\prime}$; for $\beta$-actin: (F) $5^{\prime}$-GGG GTG TTG AAG GTC TCA AA- $3^{\prime}$; for E2F1: (F) 5'-ATG TTT TCC TGT GCC CTG AG-3', (R) 5'-ATC TGT GGT GAG GGA TGA GG-3'.

\section{Fluorescence resonance energy transfer analysis}

The cells were grown in two-well Lab-Tek Chambered Coverglass slides (Nalge Nunc International, Rochester, NY, USA) in DME/F12 medium supplemented with 5\% charcoal-stripped serum and then transfected with CFPMDM2/YFP-ER $\alpha$ or CFP-SP1/YFP-ER $\alpha$ sets. All the procedures for measuring fluorescence resonance energy transfer (FRET) efficiency were previously described (Kim et al. 2005). Briefly, after transfection for $24 \mathrm{~h}$, cells were put on the stage of a Bio-Rad 2000 MP microscope system (Bio-Rad Laboratories) equipped with a Nikon T\#300 inverted microscope. The images were acquired between 5 and 15 min before and after the addition of $10 \mathrm{nM} \mathrm{E}_{2}$. FRET efficiency data were collected using two photon $820 \mathrm{~nm}$ excitation wavelength. Emission of CFP (CFP channel, donor signal) was collected using a 500DCLP dichroic and $450 / 80 \mathrm{~nm}$ filter, whereas emission of YFP (FRET channel, acceptor signal) was collected using a $528 / 50 \mathrm{~nm}$ filter. CFP-SP1/YFP-ER $\alpha$ set was used as positive control after $\mathrm{E}_{2}$ treatment in this experiment. For FRET analysis, MetaMorph software version 6.0 (Universal Imaging Corp., Downingtown, PA, USA) was used and FRET signals were corrected by subtracting the background signal as well as the donor bleed through signal. At least 50 cells per treatment were analyzed by one-way ANOVA followed by Dunnett's test.

\section{Statistical analysis}

Statistical differences between different treatments were determined using Student's $t$-test or ANOVA (Fisher's protected least significant difference), and the levels of significance are shown $(P<0 \cdot 05)$. The results are expressed as mean \pm s.E.M. for at least three replicate determinations for each experiment.

\section{Results}

\section{MDM2 enhances $E_{2}$-dependent transactivation}

Previous studies showed that $\mathrm{E}_{2}$ responsiveness was enhanced in MCF-7 cells overexpressing MDM2, and similar results were observed in Saos-2 cells transfected 
with ER $\alpha$ and MDM2 expression plasmids and an ERE reporter construct (Saji et al. 2001). In this study, we first examined the effects of endogenous MDM2 on $\mathrm{E}_{2^{-}}$ induced transactivation in ZR-75 breast cancer cells transfected with $\mathrm{pERE}_{3}$ (Fig. 1A) or $\mathrm{pSP}_{3}$ (Fig. 1B) constructs containing three tandem EREs or consensus GC-rich SP1 binding sites linked to the luciferase gene respectively. These constructs in which $\mathrm{ER} \alpha$ or $\mathrm{ER} \alpha / \mathrm{SP} 1$ activate their respective promoters represent two of the major genomic pathways of estrogen action in breast cancer cells (Hall et al. 2001, Safe \& Kim 2004) . The results show that siRNA for MDM2 significantly decreased $\mathrm{E}_{2}$-induced transactivation in cells transfected with $\mathrm{pERE}_{3}$ or $\mathrm{pSP}_{3}$ compared with cells transfected with siCT (nonspecific oligonucleotide) or untransfected cells. As a positive control, siGL2 (siRNA
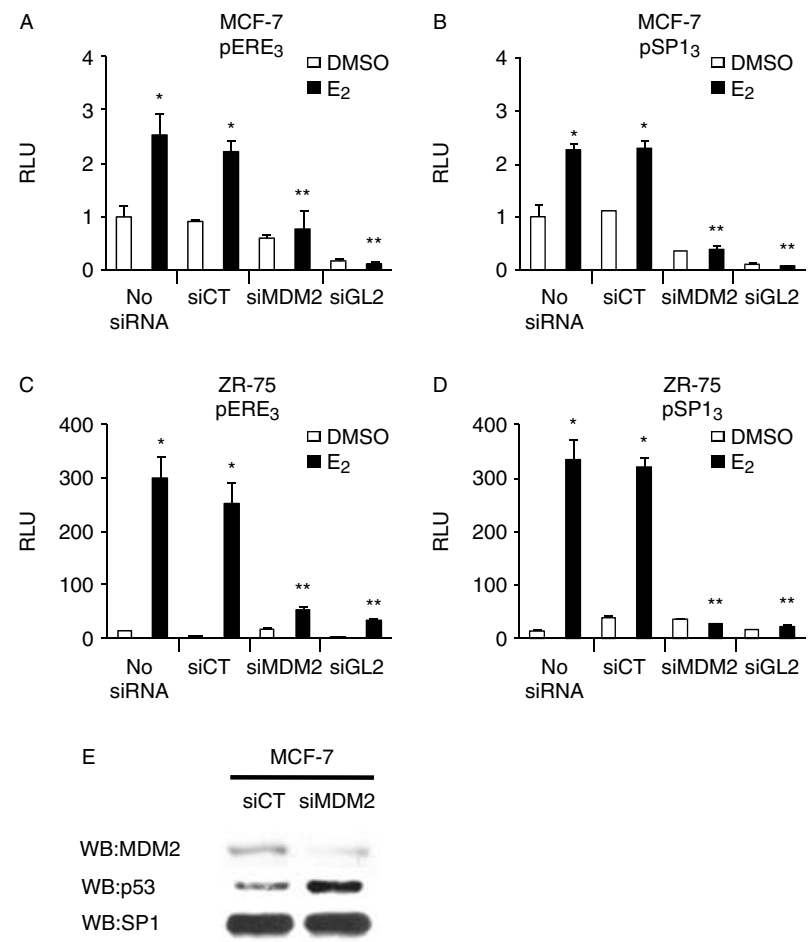

Figure 1 MDM2 knockdown inhibits estrogen-induced ER $\alpha$ and $\mathrm{ER} \alpha / \mathrm{SP}-\mathrm{mediated}$ transactivation. MCF-7 cells were transfected with $\mathrm{pERE}_{3}(\mathrm{~A})$ or $\mathrm{pSP}_{3}(\mathrm{~B})$ and $\mathrm{ZR}-75$ cells were transfected with $\mathrm{pERE}_{3}(\mathrm{C})$ or $\mathrm{pSP}_{1}$ (D) and various (or no) oligonucleotides and treated with DMSO or $10 \mathrm{nM} \mathrm{E}_{2}$. Luciferase activity was determined as described in the section 'Materials and methods'. Significant $(P<0.05)$ induction by $\mathrm{E}_{2}\left(^{*}\right)$ and inhibition by iMDM2 or iGL2 $\left(^{\star *}\right)$ are indicated. Results are expressed as means \pm S.E.M. for at least three separate determinations for each treatment group. Minimal activity was observed in cells transfected with the empty vector, and treatment with DMSO or $E_{2}$ did not induce activity. (E) MDM2 knockdown. MCF-7 cells were transfected with a nonspecific (siCT) or siMDM2 oligonucleotide, and whole cell lysates were analyzed by western blots as described in the section 'Materials and methods'. MCF-7 cells were used for whole cell lysate analysis due to higher transfection efficiency compared to ZR-75 cells. for luciferase) also decreased luciferase activity. Endogenous luciferase activity in cells transfected with $\mathrm{pSP}_{3}$ was not affected by siMDM2, suggesting that coactivation of ER $\alpha$ /specificity protein $(\mathrm{SP})$ may be due to interactions of MDM2 with $\mathrm{ER} \alpha$, not with $\mathrm{Sp}$ proteins. Figure $1 \mathrm{C}$ and $\mathrm{D}$ show that MDM2 knockdown (siMDM2) inhibited $\mathrm{E}_{2}$-induced transactivation in ZR-75 cells transfected with the $\mathrm{pERE}_{3}$ or $\mathrm{pSP}_{3}$ constructs; similar results were observed in ZR-75 cells transfected with $\mathrm{E}_{2}$-responsive $\mathrm{GC}$-rich constructs containing promoter inserts from the $E 2 F 1$ and $C A D$ genes (Wang et al. 1999, Khan et al. 2003, Ngwenya \& Safe 2003; data not shown). Moreover, in a mammalian two-hybrid assay in ZR-75 cells, we did not observe SP1-MDM2 interactions (data not shown). Results in Fig. 1E show that siMDM2 decreased siMDM2 protein expression in MCF-7 cells, increased p53 protein expression, and did not affect the levels of SP1 protein.

The effects of overexpression of MDM2 on coactivation of $\mathrm{ER} \alpha$ and $\mathrm{ER} \alpha / \mathrm{SP}$ were investigated in MCF-7 cells transfected with $\mathrm{pERE}_{3}$ (Fig. 2A) or $\mathrm{pSP}_{3}$ (Fig. 2B), and the results showed that MDM2 significantly enhanced ER $\alpha$ and ER $\alpha /$ SP-mediated transactivation and similar results were observed in ZR-75 cells (data not shown). Coactivation of ER $\alpha$ by MDM2 was further investigated in MCF-7 (Fig. 2C) and ZR-75 (Fig. 2D) cells transfected with MDM2, a GAL4-ER $\alpha$ chimeric protein (pMER), and a construct (GAL4-luc) containing five tandem GAL4 response elements. The results show that $\mathrm{E}_{2}$ significantly induced transactivation in both cell lines and this response was further enhanced by MDM2 expression. Moreover, $\mathrm{E}_{2}$-induced transactivation in MCF-7 cells transfected with pMER and GAL4-luc was significantly decreased after cotransfection with siMDM2 or siGL2 that knocks down luciferase (Fig. 2E), confirming that MDM2 coactivates ER $\alpha$-mediated transactivation.

\section{MDM2 interacts with ER $\alpha$}

It was previously reported that in a mammalian twohybrid assay in Saos-2 cells using pM-ER $\alpha$ and VP-MDM2, $\mathrm{E}_{2}$ induced transactivation (interaction); however, in GST pull-down studies ER $\alpha$ interacted with MDM2 in the presence or absence of ligand (Saji et al. 2001). Results in Fig. 3A show that in mammalian twohybrid assays in ZR-75 cells, there was increased transactivation in cells transfected with pM-MDM2 and VP-ER $\alpha$ compared with cells transfected with pM-MDM2 and VP and this interaction did not require the addition of $\mathrm{E}_{2}$. Moreover, in coimmunoprecipitation experiments with in vitro expressed ${ }^{35}$ S-labeled ER $\alpha$ and MDM2 (Xpress-tagged), both proteins interacted in the presence or absence of $\mathrm{E}_{2}$ (Fig. 3B). The interactions of $\mathrm{ER} \alpha$ and MDM2 in living cells were also investigated by FRET in cells transfected with a 

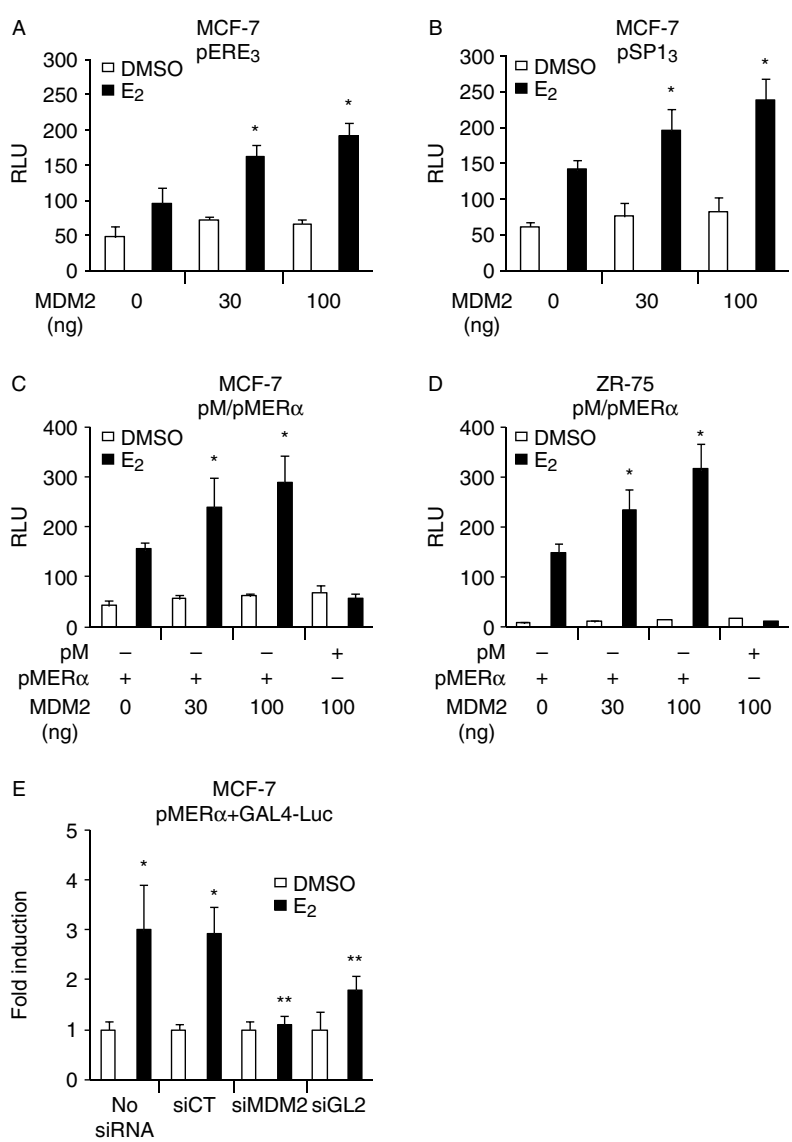

Figure 2 MDM2 coactivates $\mathrm{ER} \alpha$ and $\mathrm{ER} \alpha / \mathrm{SP}$-dependent transactivation. MCF-7 cells were treated with DMSO or $\mathrm{E}_{2}$, transfected with $\mathrm{pERE} \mathrm{E}_{3}(\mathrm{~A})$ or $\mathrm{pSP}_{1}(\mathrm{~B})$ and different amounts of MDM2 expression plasmid, and luciferase activity was determined as described in the section 'Materials and methods'. The effects of MDM2 expression in MCF-7 (C) and ZR-75 (D) cells or MDM2 knockdown in MCF-7 (E) cells on activation of $\mathrm{pM-ER} \alpha$. The cells were treated with DMSO or $10 \mathrm{nM} \mathrm{E}_{2}$, transfected with pMER and MDM2 expression plasmid, a GAL4-luc reporter construct, and oligonucleotides (as indicated); luciferase activation was determined as outlined in the section 'Materials and methods'. The results are expressed as means \pm S.E.M. for at least three replicate determinations for each treatment group as significant $(P<0.05)$ coactivation by MDM2 $\left(^{*}\right)$ and inhibition by siMDM2 or siGL2 $\left({ }^{* *}\right)$ are indicated.

CFP-MDM2 construct and a YFP-ER $\alpha$ construct. In preliminary experiments, we showed that similar to MDM2, ECFP-MDM2 also enhanced $\mathrm{E}_{2}$-dependent transactivation in ZR-75 cells transfected with pM-ER $\alpha$ /GAL4-luc (Fig. 3C). FRET analysis was determined in MCF-7 cells transfected with CFPMDM2 and YFP-ER $\alpha$ (Fig. 3D). The FRET efficiencies obtained are illustrated in Fig. 3E and show that $\mathrm{E}_{2}$ significantly enhanced this response, indicating that although both proteins directly interact in the absence of $E_{2}$, treatment with hormone clearly enhances this interaction and facilitates the energy transfer between the CFP and YFP moieties in both proteins. As a positive control for this experiment, we also show that $\mathrm{E}_{2}$ enhances YFP-ER $\alpha$ interactions with CFP-SP1 as previously reported (Kim et al. 2005). There was clearly a parallel between the significant effects of $\mathrm{E}_{2}$ on FRET efficiencies associated with YFP-ER $\alpha-$ CFP-SP1 and YFP$\mathrm{ER} \alpha-\mathrm{CFP}-\mathrm{MDM} 2$ and the $\mathrm{E}_{2}$-independent interaction of $\mathrm{ER} \alpha$ with both SP1 (Kim et al. 2005) and MDM2 (Fig. 3A and B) in coimmunoprecipitation experiments.

MDM2 contains several domains that interact with other proteins and also a zinc finger and a C-terminal RING finger domain that functions as an E3-ubiquitin ligase (Ashcroft et al. 1999, Kubbutat et al. 1999). We initially examined the interactions of wild-type and deletion variants of MDM2 (Xpress-tagged) with $\mathrm{ER} \alpha$, and Fig. 4A illustrates the electrophoretic mobilities and interactions between ${ }^{35}$ S-labeled ER and ${ }^{35}$ S-labeled wild-type MDM2 and variants expressing amino acids 1-342 (MDM2(1-342 aa)), 134-342 (MDM2(134-342 aa)), and 134-490 (MDM2(134-490 aa)). Coimmunoprecipitation experiments showed that $\mathrm{ER} \alpha$ interacted with wild-type MDM2 (lane 7), MDM2 (1-342 aa) (lane 8), MDM2 (134-490 aa) (lane 10) but not with MDM2 (134-342 aa) (lane 9). Lanes 1-6 illustrate the ${ }^{35}$ S-labeled proteins alone. Thus, ER $\alpha$ interacts with both $\mathrm{C}$ - and N-terminal domains of MDM2 but not with the 134-342 aa region, which binds CBP/p300 (Grossman et al. 1998). In contrast, coactivation studies in ZR-75 cells transfected with $\mathrm{pM}-\mathrm{ER} \alpha$ showed that only wild-type, but not the deletion variants of MDM2, coactivated ER $\alpha$ (Fig. 4B). These results suggest that multiple regions of MDM2 are required for coactivation of $\mathrm{ER} \alpha$.

\section{MDM2 enhances interactions of ER $\alpha$ with steroid receptor coactivators}

Steroid receptor coactivators (SRCs), mediator proteins, and p300 associate with ER as complexes that interact cyclically with $\mathrm{E}_{2}$-responsive gene promoters, and MDM2 has been identified as a component of these complexes (Metivier et al. 2003, Reid et al. 2003). The role of MDM2 and its interactions with coactivators has been further investigated in mammalian two-hybrid assays using coactivator-GAL4 chimeras (pM-coactivators), VP-ER $\alpha$, and GAL4-luc in ZR-75 cells. In cells transfected with pMGRIPwt, VP-ER $\alpha$ and GAL4-luc treatment with $\mathrm{E}_{2}$ induced transactivation; however, $\mathrm{E}_{2}$-dependent interactions were significantly inhibited in cells cotransfected with siMDM2, suggesting that interactions of GRIP (SRC-2) and ER $\alpha$ are mediated, in part, by MDM2 (Fig. 5A). Interactions of GRIP and MDM2 were also investigated in a mammalian two-hybrid assay in ZR-75 cells transfected with pMGRIP/GAL4-luc and VP-MDM2, and the results 


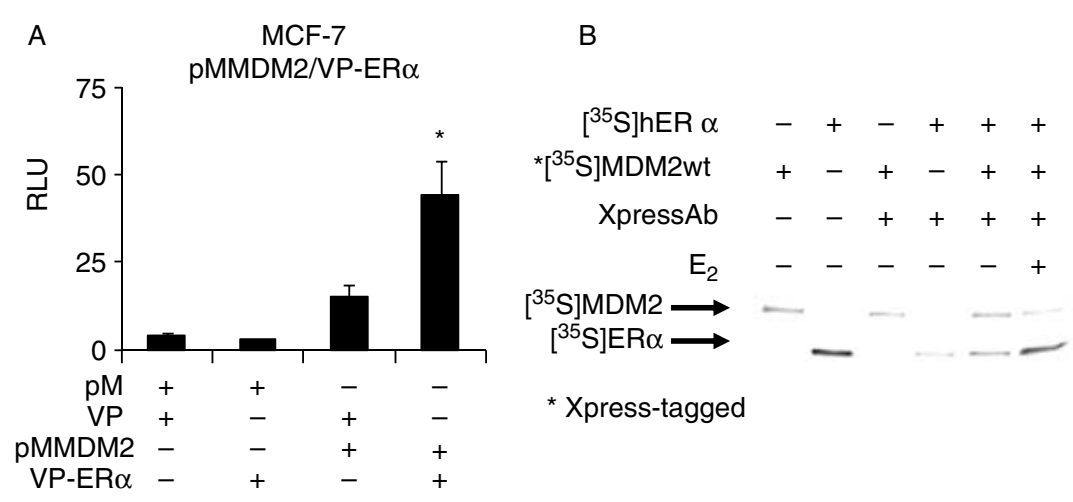

C

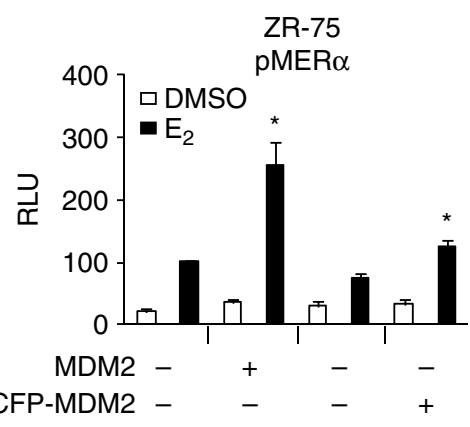

D
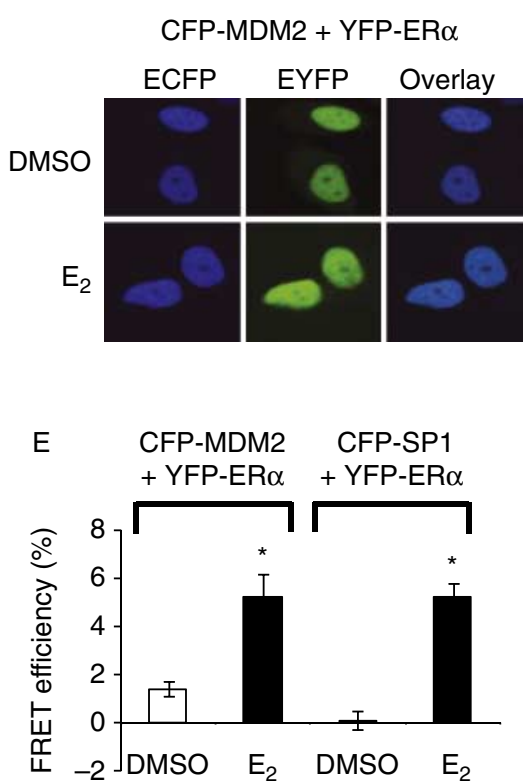

Figure 3 Interactions of MDM2 and ER $\alpha$. (A) Mammalian two-hybrid assay. Cells were transfected with various constructs and a GAL4-luc reporter gene and luciferase activity were determined as described in the section 'Materials and methods'. (B) Coimmunoprecipitation of MDM2 and ER $\alpha .\left[{ }^{35} \mathrm{~S}\right] \mathrm{ER} \alpha$ and $\left[{ }^{35} \mathrm{~S}\right] \mathrm{MDM} 2$ (Xpress-tagged) were in vitro expressed, treated with or without $E_{2}$, and coimmunoprecipitated with Xpress antibodies and then analyzed by western blots as described in the section 'Materials and methods'.

(C) Coactivation of pMER by MDM2. ZR-75 cells were treated with DMSO or $10 \mathrm{nM} \mathrm{E}_{2}$ transfected with pMER/GAL4-luc and MDM2 or ECFP-MDM2, and luciferase activity was determined as outlined in the section 'Materials and methods'. (D) MDM2: ER $\alpha$ interactions - FRET analysis. ZR-75 cells were treated with DMSO or $10 \mathrm{nM} \mathrm{E}_{2}$, transfected with CFP-MDM2 or YFP-ER $\alpha$ expression plasmids, and $\mathrm{E}_{2}$-dependent interactions were determined by FRET as described in the section 'Materials and methods'. (E) FRET efficiencies. ZR-75 cells were treated with DMSO or $10 \mathrm{nM} \mathrm{E}_{2}$ and transfected with various constructs, and FRET efficiencies were determined as described in the section 'Materials and methods'. The results of transfection studies (A, C, and E) are means \pm S.E.M. for at least three replicate determinations for each treatment group, and significant $(P<0.05)$ induction is indicated $\left({ }^{*}\right)$. Full colour version of this figure available via http://dx.doi.org/10. 1677/JME-10-0110.

show that MDM2 and GRIP do not interact in the presence or absence of $\mathrm{E}_{2}$ (Fig. 5B). However, after cotransfection with $\mathrm{ER} \alpha$, there was a significant increase in transactivation, which was observed in the absence or presence of $\mathrm{E}_{2}$ but was more pronounced in the former case. These results suggest that, although GRIP and MDM2 do not exhibit binding in a two-hybrid assay, the expression of $\mathrm{ER} \alpha$ significantly enhanced interactions between GRIP and MDM2. ER-coactivator interactions are dependent, in part, on interactions between 


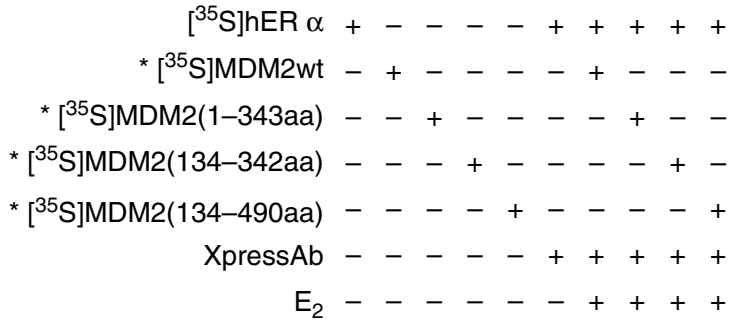

* Xpress-tagged $\left[\mathrm{S}^{35}\right] \mathrm{ER} \alpha \longrightarrow$

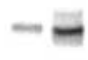

B

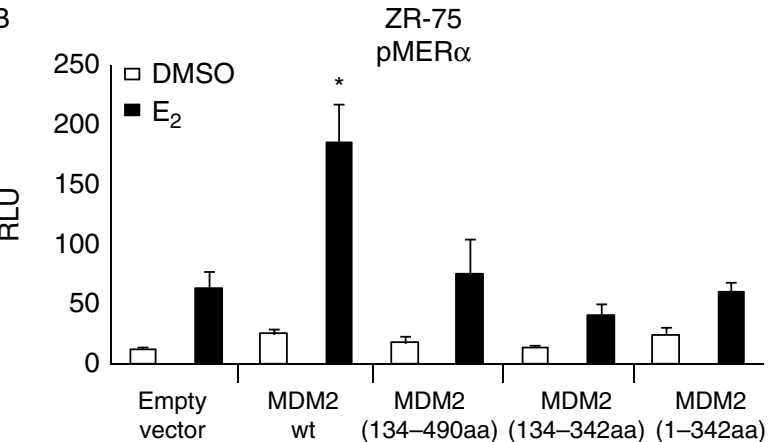

Figure 4 Physical and functional interaction of $E R \alpha$ with wild-type and variant MDM2. (A) In vitro interactions. Various $\left[{ }^{35} \mathrm{~S}\right]$-labeled proteins were in vitro expressed, coimmunoprecipitated, and analyzed by western blots as outlined in the section 'Materials and methods', and only wild-type and variant MDM2 were Xpress-tagged. (B) Coactivation of $E R \alpha$ by wild-type and deletion mutant forms of MDM2. ZR-75 cells were treated with DMSO or $10 \mathrm{nM} \mathrm{E}_{2}$, transfected with pMER/GAL4-luc and various wild-type and deletion mutant MDM2 expression plasmids, and luciferase activity was determined as outlined in the section 'Materials and methods'. The results are expressed as means \pm S.E.M. for at least three replicate determinations for each treatment group, and significant $(P<0.05)$ coactivation is indicated $\left({ }^{*}\right)$.

NR-box (LXXLL) motifs in coactivators (Torchia et al. 1997, Voegel et al. 1998) with ER $\alpha$, and Fig. 5C shows that $\mathrm{E}_{2}$ induces transactivation in ZR-75 cells transfected with VP-ER $\alpha$ and pMGRIP(LXXLL)/GAL4-luc where pMGRIP(LXXLL) is a chimera containing GAL4 fused to aa629-760 from GRIP/SRC-2, which contains an LXXLL motif. $\mathrm{E}_{2}$-dependent interactions of $\mathrm{ER} \alpha$ and GRIP(LXXLL) in the mammalian two-hybrid assay were inhibited after cotransfection with siMDM2, suggesting that MDM2 facilitates ER $\alpha$ interactions with the NR-box motif of GRIP. pMGRIP(LXXLL) did not interact with VP-MDM2 in a two-hybrid assay; however, cotransfection with $\mathrm{ER} \alpha$ in the presence or absence of $\mathrm{E}_{2}$ enhanced transactivation (Fig. 5D).
These results suggest that ER $\alpha$ enhances MDM2 interactions with the NR-box motif of GRIP.

The role of MDM2 in the interaction of ER $\alpha$ with SRC1 and SRC-3 (AIB-1) was also investigated in mammalian two-hybrid assays in ZR-75 cells (Fig. 6), and the results were similar to those observed for $\mathrm{ER} \alpha$ and GRIP. $\mathrm{E}_{2}$ induced transactivation in cells transfected with pMSRC-1/GAL4-luc plus VP-ER $\alpha$ (Fig. 6A) or pMAIB-1/ GAL4-luc plus VP-ER $\alpha$ (Fig. 6B). Cotransfection with siMDM2 inhibited basal and induced activity, and the inhibition was most pronounced for AIB-1-ER interactions. Interactions of pMSRC-1 and VP-MDM2 (Fig. 6C) or pMAIB-1 and VP-MDM2 (Fig. 6D) were not observed in mammalian two-hybrid assays; however, cotransfection with $\mathrm{ER} \alpha$ significantly enhanced transactivation in the absence or presence of $\mathrm{E}_{2}$. The hormoneinduced response was more pronounced with pMAIB-1 compared to pMSRC-1; moreover, $\mathrm{E}_{2}$ decreased transactivation in ZR-75 cells transfected with pMSRC-1, VP16-MDM2 and $\mathrm{ER} \alpha$, suggesting that liganded $\mathrm{ER} \alpha$ may inhibit SRC-1-MDM2 interactions. These results demonstrate that although MDM2 does not interact with SRCs, this protein plays a key role in enhancing $\mathrm{ER} \alpha$ interactions with the SRC coactivators. Results in Fig. $6 \mathrm{E}$ demonstrate that $\mathrm{E}_{2}$ also induces transactivation in ZR-75 cells transfected pMp300/GAL4-luc and VP-ER; however, siMDM2 slightly enhances both basal and $\mathrm{E}_{2}$-induced activity. These results demonstrate the specificity of the SRC-ER $\alpha-\mathrm{MDM} 2$ compared to that observed for p300-ER $\alpha$-MDM2 interactions where MDM2 plays a key role in coactivator ER $\alpha$ interactions but not p300-ER $\alpha$ interactions. The 'constitutive' inhibitory effect may be due to the competitive binding of both ER $\alpha$ and MDM2 to p300 (Hanstein et al. 1996, Grossman et al. 1998).

\section{MDM2 enhances $E_{2}$-dependent activation of pS2 and E2F1 and cell proliferation}

The functional effects of MDM2 on hormone-induced gene expression were investigated in p53-expressing ZR75 cells and T47D cells that do not express functional p53. In ZR-75 (Fig. 7A) and T47D (Fig. 7B) cells transfected with siMDM2, induction of E2F1 protein expression was decreased after the loss of MDM2. The role of MDM2 in hormone-induced expression of E2F1 and pS2 mRNA levels in ZR-75 (Fig. 7C) and T47D (Fig. 7D) cells was also determined, and the hormoneinduced responses were significantly decreased in cells transfected with siMDM2. Moreover, using a similar approach, knockdown of MDM2 by RNA interference in T47D cells decreased induction of CAD and cyclin D1 by $\mathrm{E}_{2}$ (data not shown). Since p53 inhibits estrogen responsiveness, it is possible that the loss of hormoneinduced transactivation in breast cancer cells transfected with siMDM2 may be due, in part, to activation of 

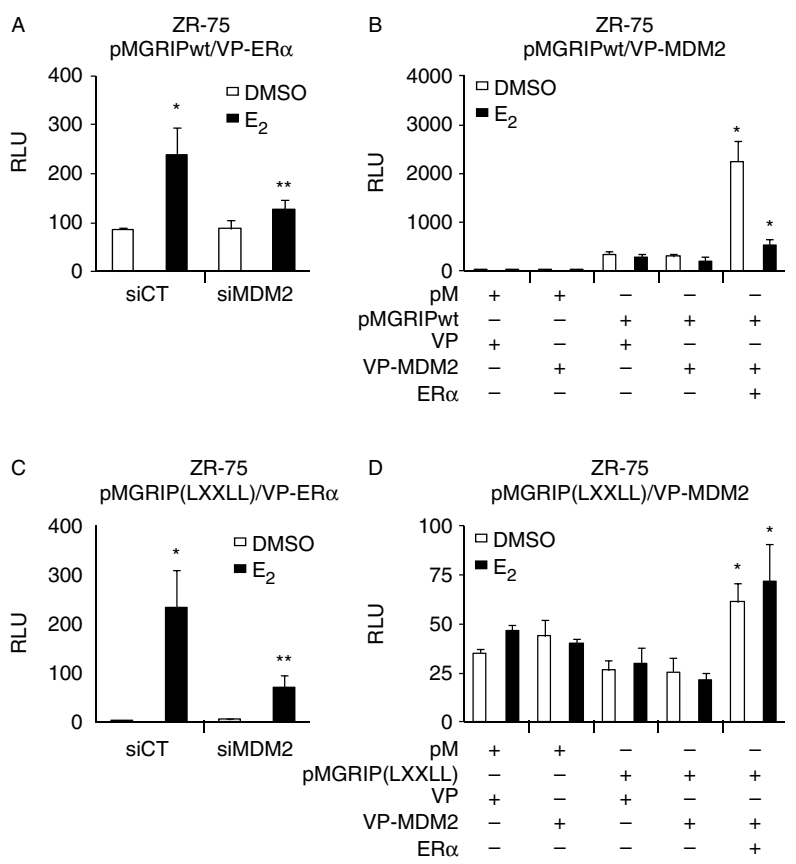

Figure 5 The effects of MDM2 on coactivation of ER $\alpha$ by GRIP (SRC-2). ZR-75 cells were treated with DMSO or $10 \mathrm{nM} \mathrm{E}_{2}$, and transfected with pMGRIPwt/VP-ER $\alpha$ and iCT or iMDM2 oligonucleotides (A) or pMGRIPwt/VP16-MDM2, empty vectors and $\mathrm{hER} \alpha(\mathrm{B})$, and luciferase activity was determined as described in the section 'Materials and methods'. ZR-75 cells were treated with DMSO or $10 \mathrm{nM} \mathrm{E}_{2}$, transfected with pMGRIP(LXXLL)/VP-ER $\alpha$ and iCT or iMDM2 oligonucleotides (C) or pMGRIP(LXXLL) /VP16-MDM2, empty vectors and $\mathrm{ER} \alpha$ (D), and luciferase activity was determined as described in the section 'Materials and methods'. The results are expressed as means \pm S.E.M. for at least three replicate determinations for each treatment group, and significantly $(P<0.05)$ enhanced interactions by $\mathrm{ER} \alpha\left(^{*}\right)$ and decreased activity by iMDM2 $\left(^{* *}\right)$ are indicated.

p53. We also compared the effects of hormone-induced transactivation in MCF-7 cells transfected with sip53, siMDM2, and their combination. $\mathrm{E}_{2}$ induced $p S 2$ and E2F1 gene expression in MCF-7 cells treated with $\mathrm{E}_{2}$ and this response was decreased after cotransfection with siMDM2 or siMDM2 plus sip53, but unaffected by sip53 alone (data not shown). Similar results were observed for induction of luciferase activity in cells transfected with $\mathrm{pSP}_{3}$ and $\mathrm{pERE}_{3}$ (data not shown), demonstrating that the effects of siMDM2 were p53 independent. Nutlin-3 is an MDM2 antagonist, which dissociates the MDM2-p53 complex, resulting in activation of p53 (Vassilev et al. 2004). In T47D cells that do not express wild-type p53, addition of Nutlin-3 did not affect induction of E2F1 by $\mathrm{E}_{2}$ (Fig. 7E). In contrast, Nutlin3 significantly decreased basal and $\mathrm{E}_{2}$-inducible E2F1 in ZR-75 cells that express wild-type p53 (Fig. 7D), demonstrating that inhibition of MDM2, like knockdown of MDM2 (Figs 1 and 2), decreased hormonal activation of E2F1. The effects of MDM2 knockdown on basal and $\mathrm{E}_{2}$-induced proliferation were also investigated in MCF-7 and ZR-75 cells (Fig. 7F). The results show that loss of MDM2 in these cells decreased both basal and hormone-induced cell growth after $96 \mathrm{~h}$, further demonstrating the critical role for MDM2 in both cell lines. These results confirm the important role of MDM2 as a coregulator of hormone-induced gene expression in breast cancer cells.

\section{Discussion}

Coactivators and other coregulatory proteins play a critical role in hormone receptor-dependent gene expression, and these nuclear proteins are essential factors for ligand-induced transcriptional activation (Blanco et al. 1998, O'Malley 2007). Initial studies describing coactivation of nuclear receptors by SRCs demonstrated several essential features of coactivator function. These included identification of NR-boxes required for specific coactivator-receptor interactions (Torchia et al. 1997, Voegel et al. 1998), histone acetyltransferase activity of some SRCs, which facilitates interaction of receptor-coregulatory complexes with promoter DNA, and interactions of coactivators with multiple domains of nuclear receptors and with other nuclear cofactors (Blanco et al. 1998, O’Malley 2007). This complexity associated with SRCs has been further magnified by ongoing studies that have identified many other classes of coactivators, which manifest their activities through ATP-dependent chromatin modeling, histone methylation, or modification of receptors through ubiquitination or sumoylation (Blanco et al. 1998, O’Malley 2007, O’Malley \& Kumar 2009).

The interactions of different functional classes of nuclear factors in ER $\alpha$-mediated transcriptional activation have been extensively investigated in chromatin immunoprecipitation (ChIP) assays, which demonstrate an ordered cycling of distinct cofactor/ER $\alpha$ complexes on and off the $\mathrm{E}_{2}$-responsive $p S 2$ gene promoter (Shang et al. 2000, Burakov et al. 2002, Metivier et al. 2003, Reid et al. 2003). MDM2, which exhibits E3-ubiquitin ligase activity, is involved in this cycling process, and previous studies have shown that MDM2 overexpression coactivates ER $\alpha$-dependent transactivation in cells transfected with ERE-promoter constructs (Saji et al. 2001). Research in this laboratory and others have demonstrated that $\mathrm{E}_{2}$ also activates genes in breast cancer cells through $\mathrm{ER} \alpha / \mathrm{SP}$ interactions with GC-rich promoters (O'Malley 2007), and we have been investigating the coactivation of $\mathrm{ER} \alpha$ and $\mathrm{ER} \alpha / \mathrm{SP}$ in breast cancer cells transfected with $\mathrm{pERE}_{3}$ and $\mathrm{pSP}_{3}$ respectively (Kim et al. 2003, Wu et al. 2004, Lee et al. 2005, Lee \& Safe 2007). Vitamin D interacting protein 150 (DRIP150) is a mediator complex protein (Koh et al. 2002, Kouzmenko et al. 2004), which coactivates $\mathrm{ER} \alpha$ and $\mathrm{ER} \alpha / \mathrm{SP} 1$, and this 

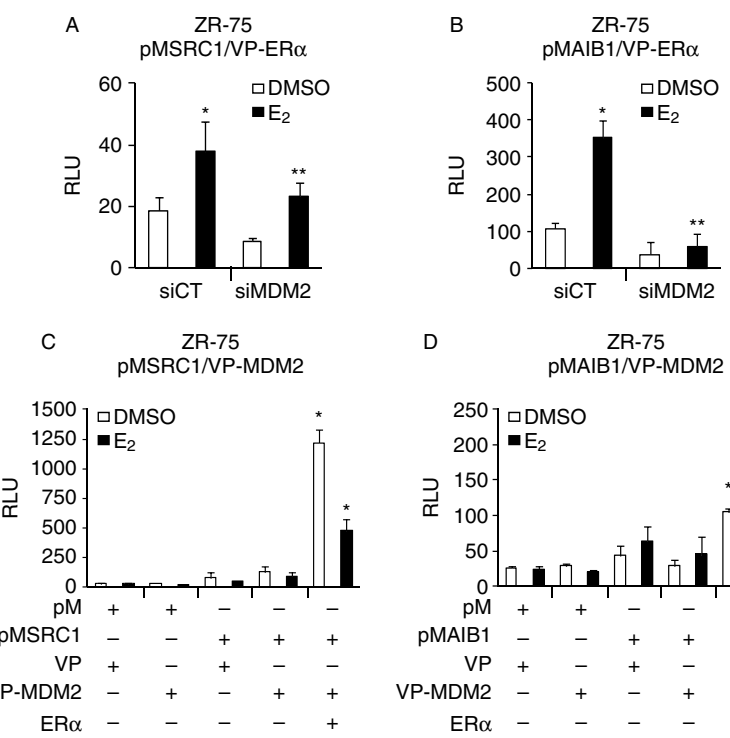

D

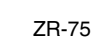
pMAIB1/VP-MDM2
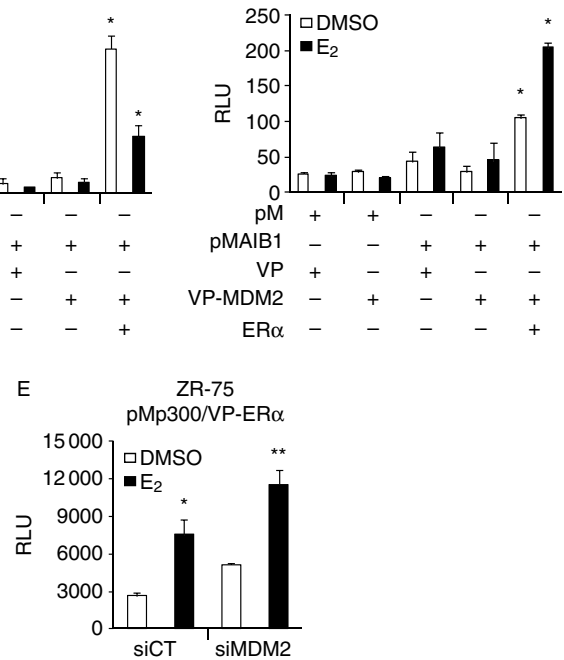

Figure 6 Effects of MDM2 on coactivation of $\mathrm{ER} \alpha$ by other coactivators and p300. ZR-75 cells were treated with DMSO or $10 \mathrm{nM} \mathrm{E}_{2}$, transfected with pMSRC-1/VP-ER $\alpha(\mathrm{A})$ or pMAIB-1/ VP-ER $\alpha$ (B), GAL4-luc and SiCT or siMDM2 oligonucleotides, and luciferase activity was determined as outlined in the section 'Materials and methods'. The effects of ER $\alpha$ on MDM2 coactivator interactions. ZR-75 cells were treated with DMSO or $10 \mathrm{nM} \mathrm{E}_{2}$, transfected with pMSRC-1/VP-MDM2 or pMAIB-1/NP-MDM2, empty vectors or $\mathrm{ER} \alpha$ and GAL4-luc, and luciferase activity was determined as described in the section 'Materials and methods'. (E) The effect of MDM2 knockdown on ER $\alpha-p 300$ interactions. ZR-75 cells were treated with DMSO or $10 \mathrm{nM} \mathrm{E}_{2}$, transfected with $\mathrm{pMp} 300 / \mathrm{VP}-\mathrm{ER} \alpha$ and GAL-luc, and luciferase activity was determined as outlined in the section 'Materials and methods'. The results are expressed as means \pm S.E.M. for at least three replicate determinations for each treatment group and significantly $(P<0.05)$ enhanced activity after transfections with $\mathrm{ER} \alpha\left(^{*}\right)$ and decreased activity after transfection with siMDM2 $\left({ }^{* *}\right)$ are indicated.

involves an $\alpha$-helical NIFSEVRVYN (amino acids 795-804) motif within a 23 amino acid sequence (789-811) in the central region of DRIP150 that does not contain an LXXLL box (Lee et al. 2005, Lee \& Safe 2007). DRIP150 had minimal effects on SP-dependent transactivation and coactivated $\mathrm{ER} \alpha$ and $\mathrm{ER} \alpha / \mathrm{SP} 1$ primarily through interactions with $\mathrm{ER} \alpha$ (Lee \& Safe 2007). In this study, we demonstrate that $\mathrm{E}_{2}$-induced transactivation in breast cancer cells transfected with $\mathrm{pSP}_{3}$ or $\mathrm{pERE}_{3}$ was significantly inhibited by knockdown of MDM2 by RNA interference (siMDM2) (Fig. 1A and B), and overexpression of MdM2 also enhanced transactivation in cells transfected with $\mathrm{pSP} 1_{3}$ or $\mathrm{pERE}_{3}$ constructs (Fig. 2A and B). We also observed that in ZR-75 and T47D cells transfected with siMDM2, there was a significant decrease in hormone-induced protein and mRNA levels (Fig. 7), demonstrating a role for MDM2 in $\mathrm{E}_{2}$-induced gene expression. These results confirm coactivation of ER $\alpha$ by MDM2 as previously reported (Saji et al. 2001) and also show that MDM2 coactivates ER $\alpha / \mathrm{SP} 1$. MDM2 did not interact with SP1 and knockdown or overexpression of MDM2 did not affect SP-dependent transactivation (Figs $1 \mathrm{~A}$ and $\mathrm{B}$ and $2 \mathrm{~A}$ and $\mathrm{C}$ ), suggesting that coactivation of $\mathrm{ER} \alpha$ and $\mathrm{ER} \alpha / \mathrm{SP}$ is primarily associated with direct interactions between MDM2 and ER $\alpha$.

MDM2 interacts with $\mathrm{ER} \alpha$ in the presence or absence of $\mathrm{E}_{2}$ (Fig. $3 \mathrm{~A}$ and $\mathrm{B}$ ) and $\mathrm{E}_{2}$ also enhances $\mathrm{ER} \alpha-\mathrm{MDM} 2$ interactions in living cells as determined by FRET analysis (Fig. 3D and E). It is clear from ChIP assays that $\mathrm{ER} \alpha, \mathrm{MDM} 2$, and other nuclear coregulatory proteins cycle on and off $\mathrm{E}_{2}$-responsive gene promoters in breast cancer cells, and there is also evidence that specific subsets of coactivators may be selectively recruited to the pS2 promoter (Metivier et al. 2003). Since constitutively expressed and transiently overexpressed MDM2 activated $\mathrm{ER} \alpha$ and $\mathrm{ER} \alpha / \mathrm{SP} 1$, it is possible that this protein may also act in concert with other nuclear cofactors such as the SRCs. Previous studies have demonstrated coactivation of ER $\alpha$ by SRCs (Blanco et al. 1998, Vassilev et al. 2004, O'Malley 2007) and corecruitment of MDM2 and SRCs to $\mathrm{E}_{2}$-responsive gene promoters and, therefore, we hypothesized that MDM2 acts, in part, through facilitating SRC-ER $\alpha$ interactions. Results in Figs 5 and 6 demonstrate that interactions of pMSRCs with VP-ER $\alpha$ are $\mathrm{E}_{2}$ dependent, and similar results were observed with interactions of VP-ER with the GRIP1 LXXLL box (GAL4GRIP(LXXLL)) (Fig. 5C). These hormone-dependent ER-SRC interactions were not surprising; however, using RNA interference with siMDM2, it was evident that MDM2 facilitated ER $\alpha-S R C$ (Figs $5 \mathrm{~A}$ and 6A, and $\mathrm{C}$ ) but not $\mathrm{ER} \alpha-\mathrm{p} 300$ (Fig. $6 \mathrm{E}$ ) interactions in a mammalian two-hybrid assay. Moreover, it was also apparent in mammalian two-hybrid assays in which cells were transfected with pMSRC and VP16-MDM2 that MDM2 did not directly interact with coactivators unless $\mathrm{ER} \alpha$ was also overexpressed, and this resulted in increased transactivation in the presence or absence of $\mathrm{E}_{2}$ (Figs $5 \mathrm{~B}$ and $6 \mathrm{~B}$ and $\mathrm{D}$ ).

These results suggest a model for MDM2 coactivation of $\mathrm{ER} \alpha$ or $\mathrm{ER} \alpha / \mathrm{SP} 1$ in which MDM2 acts alone or in combination with SRCs to enhance transactivation. This resembles, in part, a similar model proposed for $\beta$-catenin, which enhances nuclear receptor or transcription factor-mediated transactivation alone and in combination with other coactivators (Koh et al. 2002, Kouzmenko et al. 2004, Li et al. 2004, Yang et al. 2006). 
A

A $\quad$ ZR-75

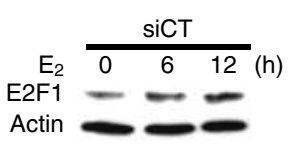

siMDM2

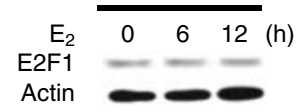

C

ZR-75
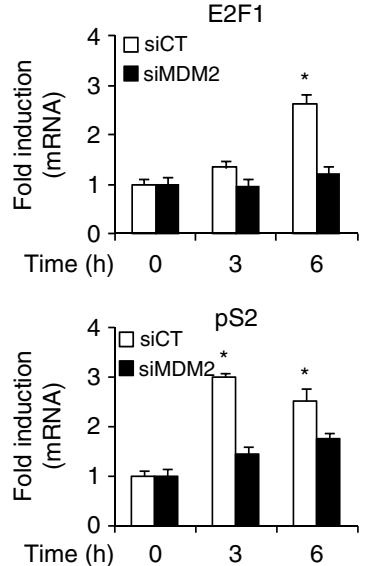

B T47D

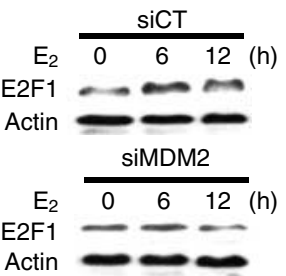

D

T47D
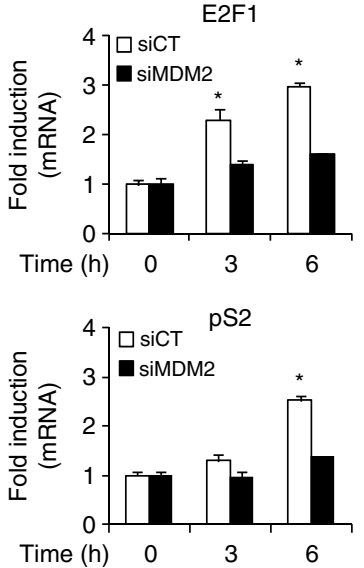

E

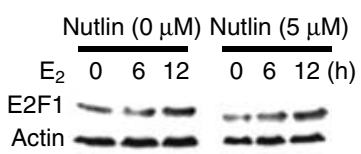

ZR-75

Nutlin $(0 \mu \mathrm{M})$ Nutlin $(5 \mu \mathrm{M})$

$\mathrm{E}_{2} \overline{0612} \overline{0612(\mathrm{~h})}$

E2F1

Actin

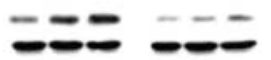

F

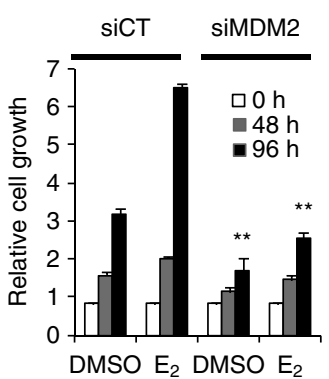

ZR-75

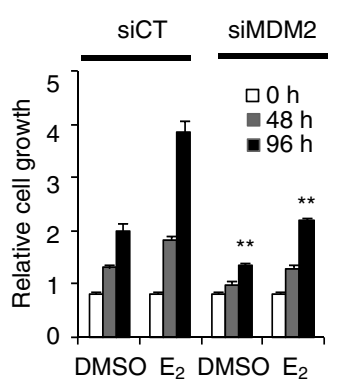

Figure $7 \mathrm{MDM} 2$ regulates $\mathrm{ER} \alpha$ - and $\mathrm{E}_{2}$-dependent genes and responses in breast cancer cells. The effects of siMDM2 on E2F1 protein levels in ZR-75 (A) and T47D (B) cells. Cells were transfected with siCT (nonspecific) or siMDM2, treated with $10 \mathrm{nM} \mathrm{E}_{2}$ for 0,6 , or $12 \mathrm{~h}$, and whole cell lysates were analyzed for E2F1 and $\beta$-actin (loading control) by western blots as described in the section 'Materials and methods'. The effects of siMDM2 on E2F1 and pS2 mRNA levels in ZR-75 (C) and T47D (D) cells. Cells were transfected with siCT (nonspecific) or siMDM2, treated with DMSO or $10 \mathrm{nM} \mathrm{E}_{2}$ for the indicated times, and mRNA levels were determined by real-time PCR as described in the section 'Materials and methods'. The results are expressed as means \pm S.E.M. for three replicate determinations and significant $(P<0.05)$ induction by $\mathrm{E}_{2}\left(^{*}\right)$ and inhibition by siMDM2 $\left.{ }^{* *}\right)$ are indicated. $(\mathrm{E})$ The effects of Nutlin. T47D or ZR-75 cells were treated with DMSO or $10 \mathrm{nME}_{2}$ in the presence or absence of $5 \mu \mathrm{M}$ Nutlin and analyzed for E2F1 and $\beta$-actin (loading control) by western blots.

(F) siMDM2 inhibits growth and hormone-induced cell proliferation. MCF-7 or ZR-75 cells were transfected with siCT or siMDM2, treated with DMSO or $10 \mathrm{nM} \mathrm{E}_{2}$, and cells were counted at various time points as described in the section 'Materials and methods'. The results are expressed as means \pm S.E.M. for three replicate determinations and significant induction by $\mathrm{E}_{2}$ (compared to DMSO) $\left(^{*}\right)$ and inhibition by siMDM2 $\left({ }^{* *}\right)$ are indicated. 
For example, $\beta$-catenin enhanced interactions between LEF1 (GAL4-LEF1) and GRIP1 (VP-GRIP), and this was primarily due to coactivation and interactions of $\beta$-catenin with LEF1 but not with GRIP1. Similarly, this study shows that MDM2 enhanced interactions between $\mathrm{ER} \alpha$ and SRCs, and this was primarily associated with coactivation and interactions with $\mathrm{ER} \alpha$ since MDM2 and SRCs did not interact. The cooperative coactivation of nuclear receptors by coactivators and other nuclear factors is highly variable. For example, CARM1 and p300 enhanced GRIP1-dependent coactivation of $\mathrm{ER} \alpha$ and the former proteins interact with GRIP1 but not with ER $\alpha$ (Chen et al. 2000). In contrast, the model for coactivation of $\mathrm{ER} \alpha$ and $\mathrm{ER} \alpha / \mathrm{SP} 1$ by SRCs and MDM2 primarily involves MDM2 interactions with ER $\alpha$ and not with SRCs.

Current studies are investigating the role of MDM2 in regulating expression of $\mathrm{E}_{2}$-responsive genes with ERE and GC-rich promoters and determining their cyclical interactions with gene promoters and other coactivators using ChIP assays. Our results clearly demonstrate that MDM2 enhances ER-dependent transactivation and cell proliferation (Fig. 7), and in transactivation assays, the loss of hormone responsiveness in cells transfected with siMDM2 was p53 independent (data not shown). Cotransfection of cells with siMDM2 alone or siMDM2 plus sip53 gave similar results, whereas knockdown of p53 alone (sip53) slightly enhanced hormone-induced transactivation, and this was consistent with a recent study (Akaogi et al. 2009) and a report showing that p53 decreases hormone-induced transactivation (Liu et al. 1999). In breast cancer, the potential prognostic significance of MDM2 or an MDM2 promoter polymorphism (SNP309) that enhances MDM2 expression has been inconsistent (Wilkening et al. 2007). However, examination of the publically available Nederlands Kanker Instituut (NKI) gene expression data from ER-positive breast cancer patients (van de Vijver et al. 2002) shows that low-MDM2 levels predict a higher overall and relapse-free survival compared with patients with highMDM2 levels (data not shown) and this observation is consistent with the results of this study showing the critical role of MDM2 in hormone-induced gene expression and growth of ER-positive breast cancer cells, suggesting that MDM2 inhibitors may be efficacious for treatment of ER-positive breast cancer patients. However, it should also be noted that the loss of MDM2 and the decreased MCF-7 and ZR-75 cell proliferation (Fig. 7F) may also be due to the parallel activation of p53 after MDM2 knockdown.

\section{Declaration of interest}

The authors declare that there is no conflict of interest that could be perceived as prejudicing the impartiality of the research reported.

\section{Funding}

This research was supported by the National Institutes of Health and is gratefully acknowledged (ES04917).

\section{References}

Akaogi K, Nakajima Y, Ito I, Kawasaki S, Oie SH, Murayama A, Kimura K \& Yanagisawa J 2009 KLF4 suppresses estrogen-dependent breast cancer growth by inhibiting the transcriptional activity of ERalpha. Oncogene 28 2894-2902. (doi:10.1038/onc.2009.151)

Ashcroft M, Kubbutat MH \& Vousden KH 1999 Regulation of p53 function and stability by phosphorylation. Molecular and Cellular Biology 19 1751-1758.

Blanco JC, Minucci S, Lu J, Yang XJ, Walker KK, Chen H, Evans RM, Nakatani Y \& Ozato K 1998 The histone acetylase PCAF is a nuclear receptor coactivator. Genes and Development 12 1638-1651. (doi:10. $1101 / \operatorname{gad} .12 .11 .1638)$

Brooks CL \& Gu W 2006 p53 ubiquitination: Mdm2 and beyond. Molecular Cell 21 307-315. (doi:10.1016/j.molcel.2006.01.020)

Bueso-Ramos CE, Manshouri T, Haidar MA, Yang Y, McCown P, Ordonez N, Glassman A, Sneige N \& Albitar M 1996 Abnormal expression of MDM-2 in breast carcinomas. Breast Cancer Research and Treatment 37 179-188. (doi:10.1007/BF01806499)

Burakov D, Crofts LA, Chang CPB \& Freedman LP 2002 Reciprocal recruitment of DRIP/mediator and p160 coactivator complexes in vivo by estrogen receptor. Journal of Biological Chemistry $\mathbf{2 7 7}$ 14359-14362. (doi:10.1074/jbc.C200099200)

Cahilly-Snyder L, Yang-Feng T, Francke U \& George DL 1987 Molecular analysis and chromosomal mapping of amplified genes isolated from a transformed mouse 3T3 cell line. Somatic Cell and Molecular Genetics 13 235-244. (doi:10.1007/BF01535205)

Chen DG, Huang SM \& Stallcup MR 2000 Synergistic, p160 coactivator-dependent enhancement of estrogen receptor function by CARM1 and p300. Journal of Biological Chemistry 275 40810-40816. (doi:10.1074/jbc.M005459200)

Fakharzadeh SS, Trusko SP \& George DL 1991 Tumorigenic potential associated with enhanced expression of a gene that is amplified in a mouse tumor cell line. EMBO Journal 10 1565-1569.

Grossman SR, Perez M, Kung AL, Joseph M, Mansur C, Xiao ZX, Kumar S, Howley PM \& Livingston DM 1998 p300/MDM2 complexes participate in MDM2-mediated p53 degradation. Molecular Cell 2 405-415. (doi:10.1016/S1097-2765(00)80140-9)

Hall JM, Couse JF \& Korach KS 2001 The multifaceted mechanisms of estradiol and estrogen receptor signaling. Journal of Biological Chemistry 276 36869-36872. (doi:10.1074/jbc.R100029200)

Hanstein B, Eckner R, DiRenzo J, Halachmi S, Liu H, Searcy B, Kurokawa R \& Brown M 1996 p300 is a component of an estrogen receptor coactivator complex. PNAS 93 11540-11545. (doi:10.1073/ pnas.93.21.11540)

Hori M, Shimazaki J, Inagawa S, Itabashi M \& Hori M 2002 Overexpression of MDM2 oncoprotein correlates with possession of estrogen receptor $\alpha$ and lack of MDM2 mRNA splice variants in human breast cancer. Breast Cancer Research and Treatment 71 77-83. (doi:10.1023/A:1013350419426)

Hsieh JK, Chan FS, O'Connor DJ, Mittnacht S, Zhong S \& Lu X 1999 RB regulates the stability and the apoptotic function of p53 via MDM2. Molecular Cell 3 181-193. (doi:10.1016/S10972765(00)80309-3)

Jones SN, Roe AE, Donehower LA \& Bradley A 1995 Rescue of embryonic lethality in Mdm2-deficient mice by absence of p53. Nature 378 206-208. (doi:10.1038/378206a0)

Khan S, Abdelrahim M, Samudio I \& Safe S 2003 Estrogen receptor/Spl complexes are required for induction of $c a d$ gene expression by $17 \beta$-estradiol in breast cancer cells. Endocrinology 144 2325-2335. (doi:10.1210/en.2002-0149) 
Kim K, Nguyen T, Saville B \& Safe S 2003 Domains of estrogen receptor $\alpha(\mathrm{ER} \alpha)$ required for $\mathrm{ER} \alpha / \mathrm{Sp} 1$-mediated activation of GC-rich promoters by estrogens and antiestrogens in breast cancer cells. Molecular Endocrinology 17 804-817. (doi:10.1210/me.2002-0406)

Kim K, Barhoumi R, Burghardt R \& Safe S 2005 Analysis of estrogen receptor $\alpha$-Sp1 interactions in breast cancer cells by fluorescence resonance energy transfer. Molecular Endocrinology 19 843-854. (doi:10.1210/me.2004-0326)

Koh SS, Li H, Lee YH, Widelitz RB, Chuong CM \& Stallcup MR 2002 Synergistic coactivator function by coactivator-associated arginine methyltransferase (CARM) 1 and $\beta$-catenin with two different classes of DNA-binding transcriptional activators. Journal of Biological Chemistry 277 26031-26035. (doi:10.1074/jbc.M110865200)

Korkolopoulou P, Christodoulou P, Kouzelis K, Hadjiyannakis M, Priftis A, Stamoulis G, Seretis A \& Thomas-Tsagli E 1997 MDM2 and p53 expression in gliomas: a multivariate survival analysis including proliferation markers and epidermal growth factor receptor. British Journal of Cancer 75 1269-1278.

Kouzmenko AP, Takeyama K, Ito S, Furutani T, Sawatsubashi S, Maki A, Suzuki E, Kawasaki Y, Akiyama T, Tabata T et al. 2004 Wnt/ $\beta$-catenin and estrogen signaling converge in vivo. Journal of Biological Chemistry 279 40255-40258. (doi:10.1074/jbc.C400331200)

Kubbutat MH, Ludwig RL, Levine AJ \& Vousden KH 1999 Analysis of the degradation function of Mdm2. Cell Growth and Differentiation 10 $87-92$.

Lee J \& Safe S 2007 Coactivation of estrogen receptor $\alpha(\mathrm{ER} \alpha) / \mathrm{Sp} 1$ by vitamin $\mathrm{D}$ receptor interacting protein 150 (DRIP150). Archives of Biochemistry and Biophysics 461 200-210. (doi:10.1016/j.abb.2006. 12.030)

Lee JE, Kim K, Sacchettini JC, Smith CV \& Safe S 2005 DRIP150 coactivation of estrogen receptor $\alpha$ in ZR-75 breast cancer cells is independent of LXXLL motifs. Journal of Biological Chemistry 280 8819-8830. (doi:10.1074/jbc.M413184200)

Levav-Cohen Y, Haupt S \& Haupt Y 2005 Mdm2 in growth signaling and cancer. Growth Factors 23 183-192. (doi:10.1080/ 08977190500196218)

Leveillard T \& Wasylyk B 1997 The MDM2 C-terminal region binds to TAFII250 and is required for MDM2 regulation of the cyclin A promoter. Journal of Biological Chemistry 272 30651-30661. (doi:10. 1074/jbc.272.49.30651)

Li H, Kim JH, Koh SS \& Stallcup MR 2004 Synergistic effects of coactivators GRIP1 and $\beta$-catenin on gene activation: cross-talk between androgen receptor and Wnt signaling pathways. Journal of Biological Chemistry 279 4212-4220. (doi:10.1074/jbc.M311374200)

Liu G, Schwartz JA \& Brooks SC 1999 p53 down-regulates ER-responsive genes by interfering with the binding of ER to ERE. Biochemical and Biophysical Research Communications 264 359-364. (doi:10.1006/bbrc.1999.1525)

Liu G, Schwartz JA \& Brooks SC 2000 Estrogen receptor protects p53 from deactivation by human double minute-2. Cancer Research 60 1810-1814.

Lukas J, Gao DQ, Keshmeshian M, Wen WH, Tsao-Wei D, Rosenberg S \& Press MF 2001 Alternative and aberrant messenger RNA splicing of the mdm2 oncogene in invasive breast cancer. Cancer Research 61 $3212-3219$.

Martin K, Trouche D, Hagemeier C, Sorensen TS, La Thangue NB \& Kouzarides T 1995 Stimulation of E2F1/DP1 transcriptional activity by MDM2 oncoprotein. Nature 375 691-694. (doi:10.1038/ $375691 \mathrm{a} 0)$

Metivier R, Penot G, Hubner MR, Reid G, Brand H, Kos M \& Gannon F 2003 Estrogen receptor- $\alpha$ directs ordered, cyclical, and combinatorial recruitment of cofactors on a natural target promoter. Cell 115 751-763. (doi:10.1016/S0092-8674(03)00934-6)

Momand J, Zambetti GP, Olson DC, George D \& Levine AJ 1992 The mdm-2 oncogene product forms a complex with the $\mathrm{p} 53$ protein and inhibits p53-mediated transactivation. Cell 69 1237-1245. (doi:10.1016/0092-8674(92)90644-R)
Montes de Oca Luna R, Wagner DS \& Lozano G 1995 Rescue of early embryonic lethality in mdm2-deficient mice by deletion of $\mathrm{p} 53$. Nature 378 203-206. (doi:10.1038/378203a0)

Ngwenya S \& Safe S 2003 Cell context-dependent differences in the induction of E2F-1 gene expression by $17 \beta$-estradiol in MCF-7 and ZR-75 cells. Endocrinology 144 1675-1685. (doi:10.1210/en.20020009)

O'Malley BW 2007 Coregulators: from whence came these "master genes". Molecular Endocrinology 21 1009-1013. (doi:10.1210/me. 2007-0012)

O'Malley BW \& Kumar R 2009 Nuclear receptor coregulators in cancer biology. Cancer Research 69 8217-8222. (doi:10.1158/0008-5472. CAN-09-2223)

Rainov NG, Dobberstein KU, Bahn H, Holzhausen HJ, Lautenschlager C, Heidecke V \& Burkert W 1997 Prognostic factors in malignant glioma: influence of the overexpression of oncogene and tumorsuppressor gene products on survival. Journal of Neuro-Oncology 35 13-28. (doi:10.1023/A:1005841520514)

Reid G, Hubner MR, Metivier R, Brand H, Denger S, Manu D, Beaudouin J, Ellenberg J \& Gannon F 2003 Cyclic, proteasomemediated turnover of unliganded and liganded ER $\alpha$ on responsive promoters is an integral feature of estrogen signaling. Molecular Cell 11 695-707. (doi:10.1016/S1097-2765(03)00090-X)

de Rozieres S, Maya R, Oren M \& Lozano G 2000 The loss of mdm2 induces p53-mediated apoptosis. Oncogene 19 1691-1697. (doi:10. 1038/sj.onc.1203468)

Safe S \& Kim K 2004 Nuclear receptor-mediated transactivation through interaction with Sp proteins. Progress in Nucleic Acid Research and Molecular Biology 77 1-36. (doi:10.1016/S0079-6603 (04) 77001-4)

Saji S, Okumura N, Eguchi H, Nakashima S, Suzuki A, Toi M, Nozawa Y, Saji S \& Hayashi S 2001 MDM2 enhances the function of estrogen receptor $\alpha$ in human breast cancer cells. Biochemical and Biophysical Research Communications 281 259-265. (doi:10.1006/bbrc.2001. 4339)

Schiebe M, Ohneseit P, Hoffmann W, Meyermann R, Rodemann HP \& Bamberg M 2000 Analysis of mdm2 and p53 gene alterations in glioblastomas and its correlation with clinical factors. Journal of Neuro-Oncology 49 197-203. (doi:10.1023/A:1006410 702284)

Sengupta S \& Wasylyk B 2004 Physiological and pathological consequences of the interactions of the p53 tumor suppressor with the glucocorticoid, androgen, and estrogen receptors. Annals of the New York Academy of Sciences 1024 54-71. (doi:10.1196/ annals.1321.005)

Shang Y, Hu X, DiRenzo J, Lazar MA \& Brown M 2000 Cofactor dynamics and sufficiency in estrogen receptor-regulated transcription. Cell 103 843-852. (doi:10.1016/S0092-8674 (00)00188-4)

Torchia J, Rose DW, Inostroza J, Kamei Y, Westin S, Glass CK \& Rosenfeld MG 1997 The transcriptional co-activator p/CIP binds CBP and mediates nuclear-receptor function. Nature 387 677-684. (doi:10.1038/42652)

Vassilev LT, Vu BT, Graves B, Carvajal D, Podlaski F, Filipovic Z, Kong N, Kammlott U, Lukacs C, Klein C et al. 2004 In vivo activation of the p53 pathway by small-molecule antagonists of MDM2. Science 303 844-848. (doi:10.1126/science.1092472)

van de Vijver MJ, He YD, van't Veer LJ, Dai H, Hart AA, Voskuil DW, Schreiber GJ, Peterse JL, Roberts C, Marton MJ et al. 2002 A geneexpression signature as a predictor of survival in breast cancer. New England Journal of Medicine 347 1999-2009. (doi:10.1056/ NEJMoa021967)

Voegel JJ, Heine MJ, Tini M, Vivat V, Chambon P \& Gronemeyer H 1998 The coactivator TIF2 contains three nuclear receptor-binding motifs and mediates transactivation through CBP binding-dependent and -independent pathways. EMBO Journal 17 507-519. (doi:10.1093/emboj/17.2.507) 
Wang W, Dong L, Saville B \& Safe S 1999 Transcriptional activation of E2F1 gene expression by $17 \beta$-estradiol in MCF-7 cells is regulated by NF-Y - Sp1/estrogen receptor interactions. Molecular Endocrinology 13 1373-1387. (doi:10.1210/me.13.8.1373)

Wilkening S, Bermejo JL \& Hemminki K 2007 MDM2 SNP309 and cancer risk: a combined analysis. Carcinogenesis 28 2262-2267. (doi:10.1093/carcin/bgm191)

Wu Q, Burghardt R \& Safe S 2004 Vitamin D-interacting protein 205 (DRIP205) coactivation of estrogen receptor $\alpha(\mathrm{ER} \alpha)$ involves multiple domains of both proteins. Journal of Biological Chemistry 279 53602-53612. (doi:10.1074/jbc.M409778200)
Yang CK, Kim JH, Li H \& Stallcup MR 2006 Differential use of functional domains by coiled-coil coactivator in its synergistic coactivator function with $\beta$-catenin or GRIP1. Journal of Biological Chemistry 281 3389-3397. (doi:10.1074/jbc. M510403200)

Received in final form 8 December 2010

Accepted 17 December 2010

Made available online as an Accepted Preprint 17 December 2010 